\title{
THE AKUNIN PROJECT
}

\author{
The Mysteries and Histories of Russia's \\ Bestselling Author
}

The Akunin Project is the first book to study the fiction and popular history of Grigorii Chkhartishvili, one of the most successful writers in post-Soviet Russia. In the first two decades of the twenty-first century, Chkhartishvili published over sixty books under the pen names Anatolii Brusnikin, Anna Borisova, Akunin-Chkhartishvili, and, most commonly, Boris Akunin. His series featuring the tsarist secret policeman Erast Fandorin has sold over 15 million books in Russia alone, making Akunin one of the bestselling authors of the post-Soviet era. Combining intertextuality, allusions, pastiche, and other markers of postmodern playfulness, many of Akunin's works have been translated into English and have also been adapted for film and television. Akunin's public profile has been further enhanced by his active involvement in mass political protests against Vladimir Putin.

Despite Akunin's international reputation as a celebrated writer, there is very little critical work on his literary output and his mysterious persona. Bringing together scholars of literature, history, and culture, The Akunin Project fills this gap by exploring the author's bestselling adventure novels and recent histories of the Russian state. The book includes translations of five short works previously unavailable in English as well as an interview with the author.

ELENA V. BARABAN is an associate professor of Russian in the Department of German and Slavic Studies at the University of Manitoba.

STEPHEN M. NORRIS is the Walter E. Havighurst professor of Russian History and the Director of the Havighurst Center for Russian and Post-Soviet Studies at Miami University in Ohio. 
This page intentionally left blank 


\section{The Akunin Project}

The Mysteries and Histories of Russia's Bestselling Author

Edited by ELENA V. BARABAN and STEPHEN M. NORRIS

UNIVERSITY OF TORONTO PRESS

Toronto Buffalo London 
(C) University of Toronto Press 2021

Toronto Buffalo London

utorontopress.com

Printed in the U.S.A.

ISBN 978-1-4875-0826-5 (cloth)

ISBN 978-1-4875-3789-0 (EPUB)

ISBN 978-1-4875-2576-7 (paper)

ISBN 978-1-4875-3788-3 (PDF)

\section{Library and Archives Canada Cataloguing in Publication}

Title: The Akunin project : the mysteries and histories of Russia's bestselling author / edited by Elena V. Baraban and Stephen M. Norris.

Names: Baraban, Elena V. (Elena Viktorovna), 1969- editor. |

Norris, Stephen M., editor.

Description: Includes bibliographical references and index.

Identifiers: Canadiana (print) 20200286390 | Canadiana (ebook) 2020028648X | ISBN 9781487508265 (cloth) | ISBN 9781487525767 (paper) |

ISBN 9781487537890 (EPUB) | ISBN 9781487537883 (PDF)

Subjects: LCSH: Akunin, B. (Boris) - Criticism and interpretation.

Classification: LCC PG3478.K78 Z49 2020 | DDC 891.73/5-dc23

University of Toronto Press acknowledges the financial assistance to its publishing program of the Canada Council for the Arts and the Ontario Arts Council, an agency of the Government of Ontario.

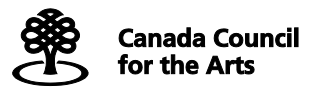

Funded by the

Financé par le Government gouvernement of Canada

\section{Conseil des Arts} du Canada

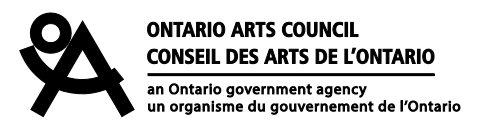

\section{Canadä}

